\title{
Maintenance of the corpus luteum after uterine transfer of trophoblastic vesicles to cyclic cows and ewes
}

\author{
Y. Heyman, Sylvaine Camous, J. Fèvre*, Wided Méziou and J. Martal* \\ Station centrale de Physiologie animale, * Laboratoire de Physiologie de la Lactation, Institut \\ National de la Recherche Agronomique, 78350 Jouy-en-Josas, France
}

\begin{abstract}
Summary. One or two trophoblastic vesicles $(0 \cdot 4-2 \mathrm{~mm}$ diam.) from cow (Day 14$)$ or ewe (Day 11-13) embryos without their disc were transferred, after culture for $24 \mathrm{~h}$, into recipients. Each vesicle was transferred into the uterine horn ipsilateral to the CL by the cervical route in heifers and surgically in ewes on Day 12 of the oestrous cycle.

In cows, daily measurements of plasma progesterone concentrations and checks for return to oestrus showed that the CL was maintained in 8 out of 12 recipients. These 8 cows had 25- to 37-day cycles while 4 recipient heifers returned to oestrus normally. Three recipients with an extended cycle were slaughtered. The dissected uterus showed that trophoblastic vesicles had developed in the uterine horns.

In ewes, the serum progesterone curve, determined in each recipient, showed that the CL was maintained in 7 out of 12 recipients. These 7 ewes had 20 - to 54-day cycles and the other 5 ewes had a normal cycle of 15-19 days comparable to that of $17.0 \pm 0.5$ days for the 6 control ewes. Whenever the CL was maintained, high blood progesterone levels were followed by rapid luteolysis. In cattle and sheep, therefore, a trophoblastic vesicle transferred into the uterus can develop in vivo, secreting the embryonic signals when there is no embryonic disc control and transforming the cyclic CL into a CL of pregnancy in about $60 \%$ of the cases. These results indicate that the early signals inhibiting luteolysis may be of trophoblastic origin and confirm that after normal embryo transfer some of the late returns to oestrus may be due to the development of trophoblastic tissue only in utero.
\end{abstract}

\section{Introduction}

Signals inhibiting luteolysis are undoubtedly produced during the elongation phase of the trophoblast in cattle and sheep. Homogenates from 17-18-day-old bovine embryos injected into the uterus of heifers on Day 14-15 of the oestrous cycle, prolong this cycle by about 3-4 days by delaying regression of the corpus luteum (Northey \& French, 1980) and it has been well established that the bovine embryo has to be present in the uterus before Day 16 to prevent luteolysis (Betteridge, Eaglesome, Randall \& Mitchell, 1980). Moor \& Rowson (1966a) demonstrated that the sheep embryo exerts a local antiluteolytic action; Martal, Lacroix, Loudes, Saunier \& Wintenberger-Torrès (1979) showed that homogenates from 14-16-day-old entire embryos injected into the uterus of cyclic ewes were able to extend the life-span of the corpus luteum for $>1$ month. At this stage of early development, the conceptus is very long and the trophoblast is about 50 times more developed than the embryonic disc. Martal et al. (1979) suggested that an antiluteolytic substance extracted from the homogenates and called trophoblastin might be secreted by the trophoblast rather than by the embryonic disc cells but this has not yet been demonstrated. 
The respective roles of the embryonic disc and the trophoblast in the mechanisms controlling the establishment of pregnancy have not yet been established. In cattle, embryonic mortality after embryo transfer is high and leads to late returns to oestrus (Markette, Seidel \& Elsden, 1980). This wastage is significantly greater with embryos cultured before transfer (46\% compared with $29 \%$ : Renard, Heyman \& Ozil, 1980). The deleterious effect of culture, which only becomes apparent at implantation, mainly affects the fragile cells of the embryonic disc (Wintenberger-Torrès, 1967). Some cases of embryonic mortality might be due to the development in utero of only trophoblastic tissue which leads to a longer oestrous cycle (Martal, 1981a).

The present experiments were designed to establish whether the conceptus from which the embryonic disc has been removed is capable of development in vivo and of maintaining the corpus luteum in recipient cows and ewes. Part of this work has been presented in abstract form (Heyman, Camous, Fèvre \& Martal, 1982).

\section{Materials and Methods}

Animals. The studies were carried out on 24 pure-bred or cross-bred Charolais heifers and on 32 primiparous or multiparous ewes of the Préalpes-du-Sud breed.

Embryo donor animals. Bovine embryos were obtained from heifers superovulated by injections of pituitary extracts: $32 \mathrm{mg}$ FSH-P (Burns-Biotec, Omaha, U.S.A.) per animal in decreasing doses according to the treatment recommended by Elsden, Nelson \& Seidel (1978). Embryos were recovered, by the cervical route, 14 days after oestrus (designated Day 0) and artificial insemination. The uterine horns were flushed with phosphate-buffered saline solution (Tervit, Whittingham \& Rowson, 1972) supplemented with $0.2 \%(\mathrm{w} / \mathrm{v})$ bovine serum albumin (fraction V powder: Sigma, St Louis, MO, U.S.A.).

Ovine embryos were obtained from ewes synchronized with progestagen-impregnated intravaginal sponges (30 mg $17 \alpha$-acetoxy-9 $\alpha$-fluoro-11 $\beta$-hydroxyprogesterone: Searle Intervet Ltd, Angers, France) (Robinson, 1965; Shelton, 1965) and superovulated with 400 i.u. PMSG (Searle) on Day 14 of the synchronized oestrous cycle. The ewes were mated twice on the day of oestrus, which was designated Day 0. On Days 11-13 of pregnancy, embryos were obtained surgically by clamping the cervix and flushing both uterine horns (with the buffer described above) from the tip of one horn out through a cannula inserted into the tip of the uterine horn contralateral to the corpus luteum.

Recipient animals. The oestrous cycles of 12 recipient heifers were synchronized using two injections of $500 \mu \mathrm{g}$ cloprostenol (Estrumate: ICI-Pharma, Reims, France) given 11 days apart. On Day 12 of the synchronized cycle each recipient received 1 or 2 trophoblastic vesicles from Day 14 bovine embryos. Cervical transfers were performed with the Cassou gun (Instruments de Médecine Vétérinaire, L'aigle, France) (Renard, Heyman \& du Mesnil du Buisson, 1977). The vesicles were introduced with $0.2 \mathrm{ml}$ Medium B2 (Api-System, La Balme les Grottes, Montalieu-Vercieu, France) (Ménézo, 1976) from a French straw and deposited into the middle third of the uterine horn ipsilateral to the corpus luteum. The side of the corpus luteum was detected by rectal palpation. A control group of 5 recipient heifers were injected with $0.2 \mathrm{ml}$ Medium B2 only by the same method.

Twelve recipient ewes, synchronized in the same way as the donors, were anaesthetized on Day 12 with halothane (Fluothane: ICI-Pharma), and the corpora lutea were marked with India ink through a mid-line abdominal incision. Using a French straw introduced through a puncture, two trophoblastic vesicles from 11-13-day-old ovine embryos in $0.2 \mathrm{ml}$ Medium B2 were then transferred to the middle third of the uterine horn adjacent to the corpus luteum and the puncture in the uterine wall was sewn up with catgut.

A control group of 6 recipient ewes operated upon in the same conditions were injected in utero with $0.2 \mathrm{ml}$ Medium B2 to check the possible effect of the surgical intervention upon the length of the oestrous cycle. 
Preparation of trophoblastic vesicles. After recovery of bovine embryos at Day 14 and ovine embryos at Days 11-13, blastocysts in their early elongation phase $(0.4-40 \mathrm{~mm}$ length) were used to prepare trophoblastic vesicles. Each embryo was easily cut into 2 or 3 pieces to remove the embryonic disc as shown in Pl. 1, Figs $1 \& 2$.

Each piece of tissue was cultured for $24 \mathrm{~h}$ at $38^{\circ} \mathrm{C}$ in $500 \mu$ l Medium B2 in controlled gas conditions $\left(20 \% \mathrm{O}_{2}, 5 \% \mathrm{CO}_{2}, 75 \% \mathrm{~N}_{2}\right)$. During culture, pieces of trophoblastic tissue changed into spherical vesicles (Pl. 1, Fig. 3) which were used for transfers. These spheres were called trophoblastic vesicles because of the importance of the trophectoderm at this embryonic stage. The size of the transferred vesicles ranged from 0.4 to $2 \mathrm{~mm}$ diameter in both species. Representative bovine and ovine vesicles were examined histologically after culture for $24 \mathrm{~h}$.

Histological analysis of trophoblastic vesicles. Samples were fixed in $2 \%$ glutaraldehyde in $0.15 \mathrm{M}$ cacodylate buffer, $\mathrm{pH} 7 \cdot 3$, then in $1 \% \mathrm{OsO}_{4}$ in the same buffer for $1 \mathrm{~h}$ each, dehydrated in ethanol and embedded in Epon. Semi-thin sections were stained with toluidine blue. Ultrathin sections were counterstained with uranyl acetate and lead citrate.

Observations after vesicle transfer. Each recipient cow was teased twice daily with a vasectomized bull to detect oestrus. To determine the functional life of the corpus luteum a $10 \mathrm{ml}$ jugular venous sample was collected daily in a heparinized tube (Becton-Dickinson, Grenoble, France) until a return to oestrus. Samples were centrifuged at $2500 \mathrm{~g}$ for $15 \mathrm{~min}$ and the plasma was stored at $-20^{\circ} \mathrm{C}$ until assayed for progesterone.

Three recipient heifers exhibiting an extended oestrous cycle after vesicle transfer were slaughtered and their genital tracts were removed for examination. The uterine horns were dissected to determine whether membranes were present inside the uterine lumen. Samples of uterine horn and membranes for histological study were fixed in Bouin's solution, embedded in paraffin wax, cut into $10 \mu \mathrm{m}$ sections and stained with haematoxylin and eosin.

The sexual behaviour of the recipient ewes was checked each morning and evening by means of vasectomized rams. Blood samples were collected daily in tubes (Becton-Dickinson) without anticoagulant and serum was centrifuged and stored at $-20^{\circ} \mathrm{C}$ until assayed for progesterone. One recipient ewe exhibiting a prolonged high level of progesterone after transfer was slaughtered and its genital tract was removed to check the development of the trophoblastic vesicle and corpora lutea.

Plasma and serum progesterone assays. Progesterone concentrations were determined by a double-antibody radioimmunoassay. The progesterone antiserum was obtained by immunization of rabbits against progesterone-11 $\alpha$-hemisuccinate-bovine serum albumin. The antiserum exhibited the greatest cross-reactivity $(7 \cdot 5 \%)$ with $5 \alpha$-pregnane-3,20-dione and with desoxycorti-

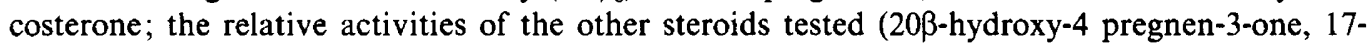
hydroxyprogesterone, $3 \beta$-hydroxy-5-pregnen-20-one, and $5 \beta$-pregnane- $3 \alpha, 20 \alpha$-diol) were $<2 \%$. The serum or plasma samples were extracted with hexane and the rabbit progesterone antiserum was precipitated by sheep globulin antiserum. Control plasma or serum from an ovariectomized ewe was regularly introduced into each standard curve. The limit of sensitivity for the assay was about $0.2 \mathrm{ng} / \mathrm{ml}$ and the intra- and inter-assay coefficients of variation were about 10 and $15 \%$, respectively.

Luteolysis was considered to have been completed on the day when progesterone concentration fell below $1 \mathrm{ng} / \mathrm{ml}$, and to have been inhibited when this occurred after Day 24 in the cow and after Day 19 in the ewe.

\section{Results}

Maintenance of the corpus luteum after vesicle transfer

Cattle. Of the 12 recipient heifers in which 1 or 2 trophoblastic vesicles were transferred, 8 $(66 \%)$ exhibited a prolonged oestrous cycle exceeding 25 days (Table 1). However, in the 5 control 
Table 1. Inhibition of cyclic luteolysis after trophoblastic vesicle transfer in (a) experimental and (b) control heifers*

\begin{tabular}{ccccc}
\hline & & \multicolumn{2}{c}{ Day of: } \\
\cline { 3 - 4 } $\begin{array}{c}\text { No. of } \\
\text { recipient }\end{array}$ & $\begin{array}{c}\text { No. of } \\
\text { transferred } \\
\text { vesicles* }\end{array}$ & $\begin{array}{c}\text { Next } \\
\text { oestrus }\end{array}$ & $\begin{array}{c}\text { Completion } \\
\text { of } \\
\text { luteolysis }\end{array}$ & $\begin{array}{c}\text { Maintenance } \\
\text { of CL }\end{array}$ \\
\hline (a) & & & & \\
414 & 2 & $>25$ & $>25 \dagger$ & + \\
415 & 2 & $>28$ & $>28 \dagger$ & + \\
425 & 2 & 25 & 25 & + \\
430 & 1 & 18 & 18 & - \\
439 & 1 & 37 & 37 & + \\
453 & 2 & $-\ddagger$ & 23 & - \\
468 & 2 & 32 & 31 & + \\
484 & 2 & 27 & 26 & + \\
541 & 2 & $-\ddagger$ & 21 & - \\
547 & 2 & 35 & 35 & + \\
550 & 2 & $>27$ & $>27 \dagger$ & + \\
561 & 2 & 21 & 21 & - \\
\hline
\end{tabular}

(b)

\begin{tabular}{lllll}
383 & - & 21 & 21 & - \\
385 & - & 21 & 21 & - \\
391 & - & 22 & 22 & - \\
420 & - & 20 & 21 & - \\
434 & - & 21 & 21 & - \\
\hline
\end{tabular}

* With $0 \cdot 2 \mathrm{ml}$ Medium B2; control heifers received $0 \cdot 2 \mathrm{ml}$ Medium B2 only.

$\dagger$ Slaughtered on Days 25, 28 and 27 respectively.

$\ddagger$ Not observed.

recipients cyclic luteolysis was completed normally $21 \cdot 0 \pm 0 \cdot 3$ days after the previous oestrus. In the animals with prolonged cycles, regression of the corpus luteum occurred between Days 25 and 37 , as was reflected in the plasma levels of progesterone (Text-fig. 1).

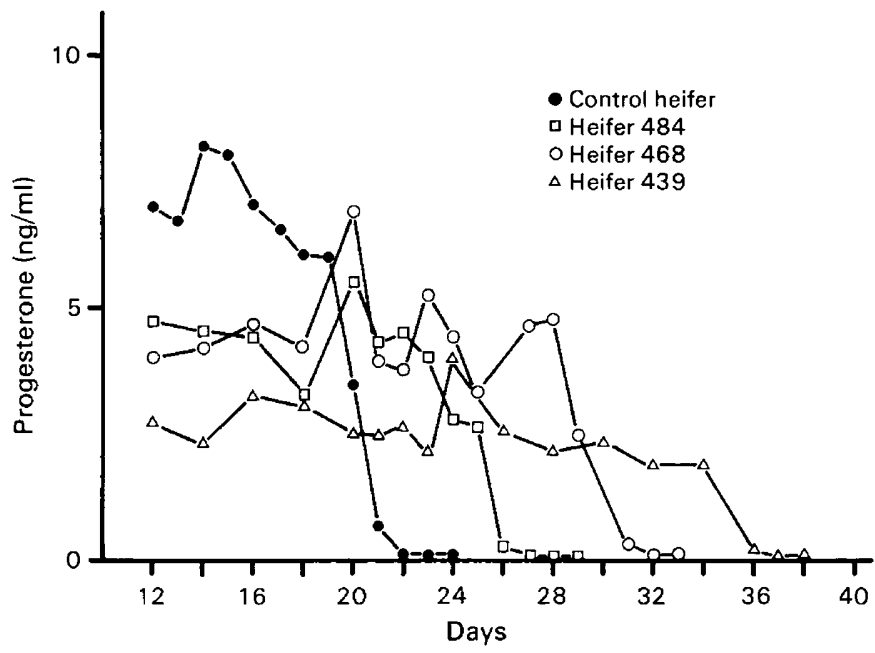

Text-fig. 1. Typical plasma progesterone patterns in recipient heifers after transfer of bovine trophoblastic vesicles and in a control heifer. 
Sheep. Serum levels of progesterone showed prolonged maintenance of the corpus luteum in 7 out of the 12 recipient ewes to which 2 vesicles were transferred (58\%, Table 2). In Ewe 9425 , the corpus luteum was maintained until Day 54 . The 6 control recipient ewes exhibited normal oestrous cycles of $17 \pm 0.5$ days (Text-fig. 2).

Table 2. Inhibition of cyclic luteolysis after transfer of trophoblastic vesicles in (a) experimental and (b) control ewes

\begin{tabular}{|c|c|c|c|c|}
\hline \multirow[b]{2}{*}{$\begin{array}{l}\text { No. of } \\
\text { recipient }\end{array}$} & \multirow[b]{2}{*}{$\begin{array}{c}\text { No. of } \\
\text { transferred } \\
\text { vesicles* }\end{array}$} & \multicolumn{2}{|c|}{ Day of: } & \multirow[b]{2}{*}{$\begin{array}{c}\text { Maintenance } \\
\text { of CL }\end{array}$} \\
\hline & & $\begin{array}{c}\text { Trophoblastic } \\
\text { vesicle } \\
\text { stage }\end{array}$ & $\begin{array}{c}\text { Completion } \\
\text { of } \\
\text { luteolysis }\end{array}$ & \\
\hline \multicolumn{5}{|l|}{ (a) } \\
\hline 9425 & 2 & 11 & 54 & + \\
\hline 7573 & 2 & 11 & 28 & + \\
\hline 9514 & 2 & 11 & 19 & - \\
\hline 9066 & 2 & 11 & 16 & - \\
\hline 5535 & 2 & 13 & 16 & - \\
\hline 9026 & 2 & 13 & 15 & - \\
\hline 9359 & 2 & 13 & 20 & + \\
\hline 9571 & 2 & 13 & 16 & - \\
\hline 5559 & 2 & 13 & $>26 \dagger$ & + \\
\hline 6019 & 2 & 13 & 22 & + \\
\hline 0557 & 2 & 13 & 22 & + \\
\hline 6138 & 2 & 13 & 23 & + \\
\hline \multicolumn{5}{|l|}{ (b) } \\
\hline 3505 & - & & $17 \cdot 5$ & - \\
\hline 3123 & - & & 19 & - \\
\hline 3154 & - & & 16 & - \\
\hline 2247 & - & & 16 & - \\
\hline 3027 & - & & $16 \cdot 5$ & - \\
\hline 3175 & - & & 17 & - \\
\hline
\end{tabular}

* With $0.2 \mathrm{ml}$ Medium B2; control ewes received $0.2 \mathrm{ml} \mathrm{Medium} \mathrm{B2}$ only.

+ Slaughtered on Day 26.

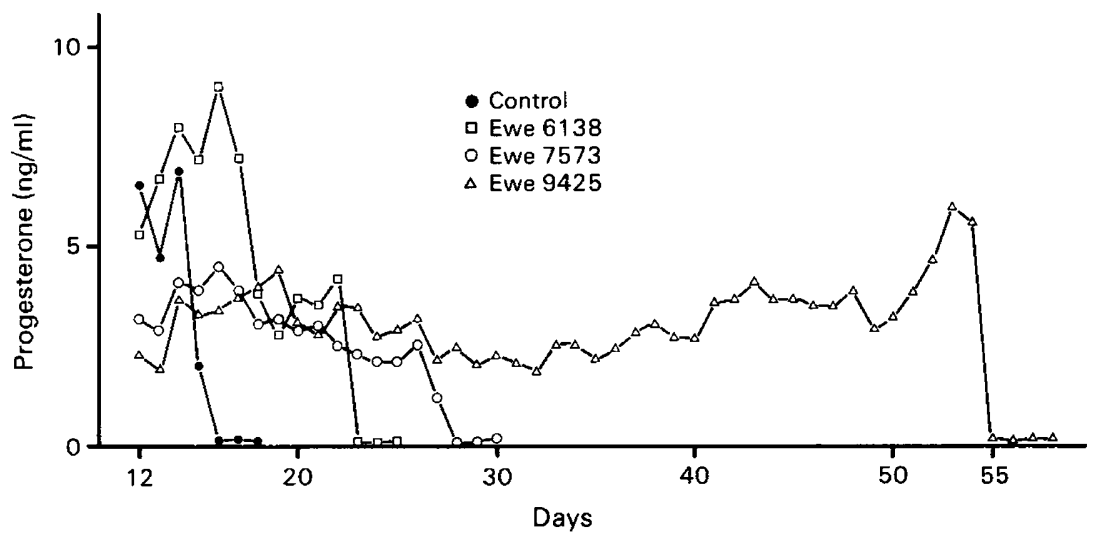

Text-fig. 2. Typical serum progesterone patterns in recipient ewes after transfer of ovine trophoblastic vesicles and in a control ewe. 
Development of transferred ovine and bovine trophoblastic vesicles in vivo

Structure of vesicles before transfer. Semithin sections from bovine trophoblastic vesicles fixed after culture, showed them to be lined on the inside with a thin layer of endoderm (Pl. 1, Fig. 4). Bovine trophoblastic cells observed by electron microscopy seemed to have an intense secretory activity, as indicated by their numerous inclusions (Pl. 2, Fig. 5).

Development of the vesicles in utero. Three recipient heifers exhibiting an extended cycle and slaughtered on Day 25, 27 or Day 28 (Table 1), each possessed a functional corpus luteum of $7 \cdot 5,8 \cdot 5$ and $11.0 \mathrm{~g}$, respectively. Dissection of the uterine horns revealed partly degenerating membranes in each horn, free of any fluid. Transverse and longitudinal histological sections of bovine uterine horn segments showed, in the lumen, trophoblastic tissue against the uterine epithelium (PI. 2, Figs 6 and 7). These membranes seemed to be degenerating in Heifer 550 (Pl. 2, Fig. 6) but were still in good condition in Heifer 414 (P1. 2, Fig. 7).

In recipient Ewe 5559 slaughtered on Day 26, dissection of the uterine horns showed a threadlike membrane about $10 \mathrm{~cm}$ long inside the lumen. There was no fluid inside and this membrane appeared to be opaque and necrotic.

\section{Discussion}

In cyclic cows and ewes, 11-14-day-old embryos from which the embryonic disc was removed were capable of developing in utero after transfer and of extending the life of the corpus luteum in about $60 \%$ of the animals. Sham-transfer treatments had no effect on the length of the oestrous cycle. After culture for $24 \mathrm{~h}$, bovine trophoblastic vesicles were almost as efficient as similarly cultured intact embryos $(62 \%$ : Renard et al., 1980) in maintaining the corpus luteum. The life-span of corpus luteum of recipient heifers after transfer of bovine vesicles was similar to that obtained by Humblot, Dalla Porta \& Schwartz (1982) and Dalla Porta (1982), and slightly longer than that obtained by Northey \& French (1980) after twice daily uterine injections of homogenates from 1619-day-old entire embryos.

In the ewe, the percentage of recipients showing maintenance of the luteal structures after

\section{PLATE 1}

Fig. 1. Intact bovine embryo. $\times 40$.

Fig. 2. Bovine embryo after cutting to remove the embryonic disc (ED). $\times 40$.

Fig. 3. Bovine trophoblastic vesicle after culture for $24 \mathrm{~h}$. Arrow indicates the scar after cutting. $\times 70$.

Fig. 4. Semithin section of bovine trophoblastic vesicle after culture for $24 \mathrm{~h}$, stained with toluidine blue. Note the endoderm layer $(\mathrm{E})$ and trophectoderm $(\mathrm{T}) . \times 270$.

\section{PLATE 2}

Fig. 5. Electron micrograph of part of a trophoblastic vesicle from a 14-day cow embryo. Note numerous vesicular inclusions (V) in the trophoblast cells (TC) and their comparative scarcity in the endoderm layer (E). Arrows indicate junction region. MV, microvilli; N, nucleus; L, lipid droplet; B, blastocoele. $\times 6000$.

Fig. 6. Transverse section of uterine horn from recipient heifer No. 550 slaughtered on Day 27. Note partially degenerating trophoblastic membranes (TM) inside the uterine lumen (L). E, epithelium; S, stroma; H\&E, $\times 270$.

Fig. 7. Longitudinal section of a uterine horn from recipient heifer No. 414 slaughtered on Day 25. Note trophoblastic membranes (TM) against the uterine epithelium (E). L, uterine lumen; S, stroma. H\&E, $\times 270$. 


\section{PLATE 1}

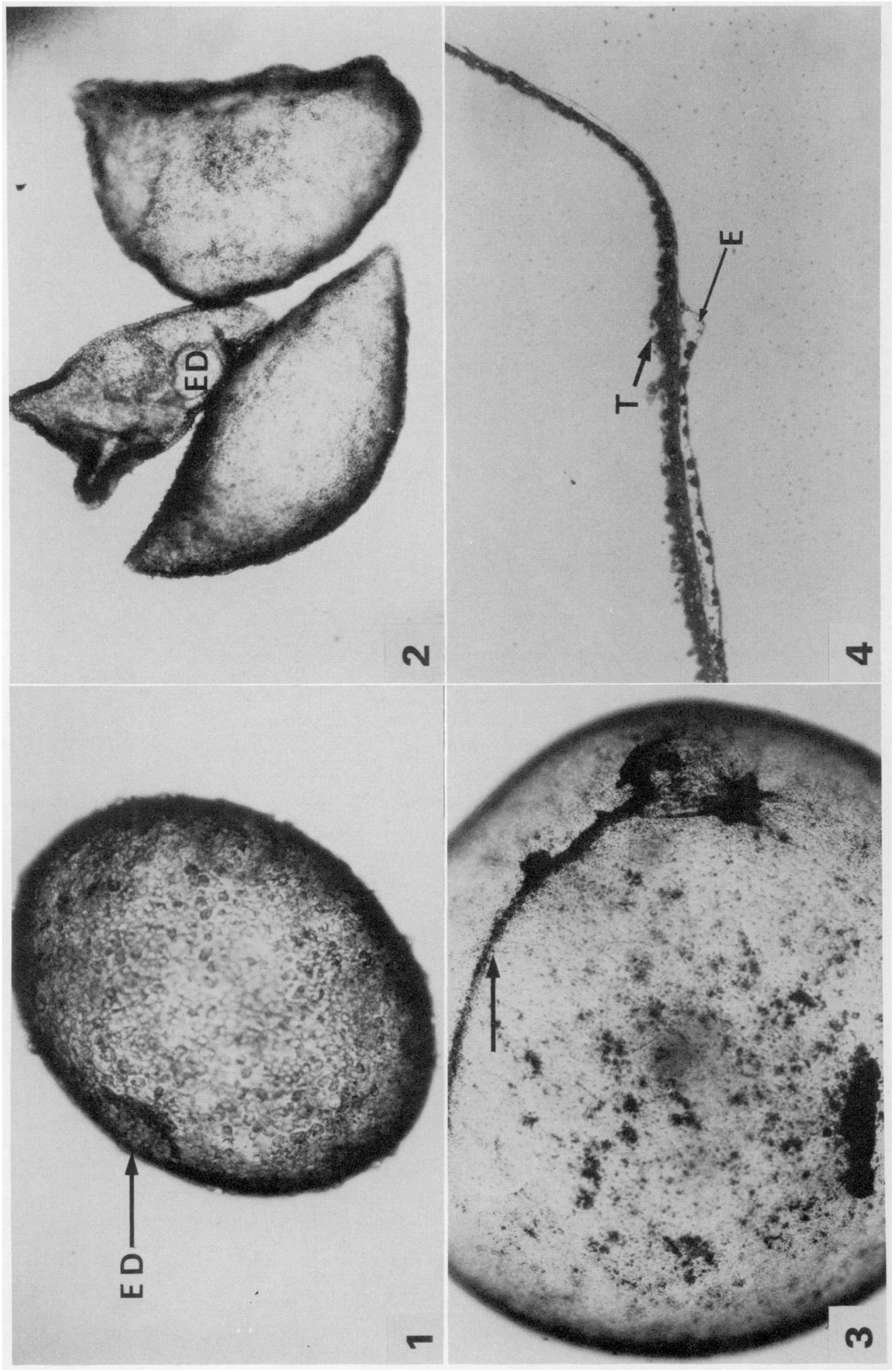




\section{PLATE 2}
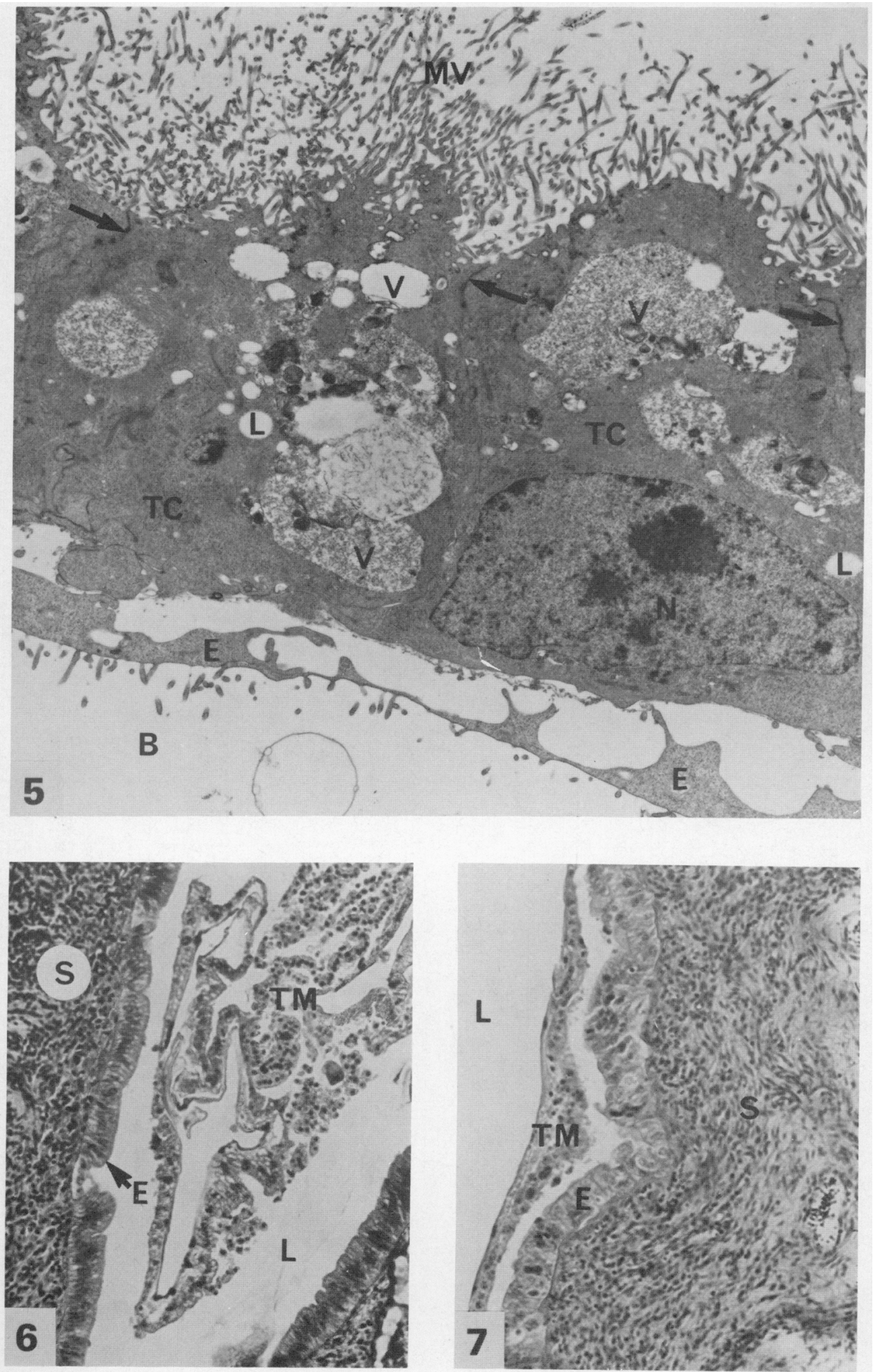
vesicle transfer was comparable to that obtained by direct transfer of intact embryos $(64 \%$ : Moor $\&$ Rowson, 1966b) or by daily intrauterine injections of homogenates from 14-16-day-old embryos (Rowson \& Moor, 1967; Martal et al., 1979). Transfer of trophoblastic vesicles to study the control of the luteal function by the embryo therefore seems to be a very useful method as compared to multiple injections of embryo homogenates. Although the common stage of Day 12 was chosen for vesicle transfer in both species in this study, inhibition of luteolysis might be expected after transfers up to Day 13 in the ewe (Moor \& Rowson, 1966b) and Day 15-16 in the cow (Betteridge $e t$ al., 1980, Northey \& French, 1980).

These transfer experiments showed that trophoblastic vesicles remain alive in utero for the time required for the expression of their signals to maintain the corpus luteum. According to Martal (1981b) this critical phase lasts about 10 days (Days 12-22 of pregnancy) in sheep. Nevertheless, some trophoblastic vesicles may have degenerated before the end of this period, since 4 daily injections of embryonic homogenates can sometimes maintain corpora lutea for a period longer than 22 days (Martal et al., 1979). Generally, two vesicles were injected into the recipient cows and ewes. This corresponded to a quantity slightly smaller than that of the entire membranes of an intact embryo just at the beginning of elongation, since a small amount of trophoblastic tissue around the removed embryonic disc was always lost. However, in one cow, even transfer of a single vesicle led to the same result. The importance of the local effect of the embryo on the inhibition of the cyclic luteolysis (Moor \& Rowson, 1966c) and the very small amount of transferred material suggests that the embryonic membranes have a very high secretory activity or(and) a large growth capacity. This was supported by the observation that, in slaughtered heifers and a ewe with extended cycles, these trophoblastic vesicles had become thread-like in vivo. The histological sections presented here show this development in vivo, whereas cultured vesicles remained spherical in vitro, in our experimental conditions, even after several weeks of culture. This suggests that the uterus, in addition to exerting a possible mechanical effect, might secrete one or several, still unknown, substances inducing elongation. These findings are in agreement with those of Lawson, Parr \& Cahill (1983) on the maternal control of blastocyst growth after asynchronous transfer in sheep.

The 24-h culture of trophoblastic vesicles gave time for morphological selection of those to be transferred: only vesicles with normal swelling were used. In addition, the culture of these trophoblastic vesicles is useful for analysing their secretions. After culture for 5 days the vesicles were still able to inhibit luteolysis in recipient animals (unpublished data).

Finally, since trophoblastic vesicles without the embryonic disc are still able to inhibit the luteolytic activity of the uterus, it can be concluded that the antiluteolytic and luteotrophic substances are mainly secreted by the embryonic membranes. The mechanisms of control of luteal function by the ruminant embryo have been discussed previously (Martal, 1981b). Because of the abundance of trophoblastic cells, as compared to the very small number of endodermic cells, and because of their very high secretory activity, the secretion of signals inhibiting luteolysis seems likely to take place in the trophectoderm, the endodermic tissue playing the essential role of sustaining the trophectoderm, although endodermic cells are probably also necessary for continued growth of trophectoderm as shown in the mouse (Ilgren, 1981). Amongst these signals, trophoblastin is an antiluteolytic protein whose biochemical nature is still unknown (Martal et al., 1979) although it might correspond to the protein X of Godkin, Bazer, Moffatt, Sessions \& Roberts (1982).

Nevertheless, further studies are still required to determine whether, in the intact embryo, the embryonic disc or the endoderm are involved in inducing the secretion of signals that inhibit regression of the corpus luteum.

We thank N. Chêne, D. Chêne, P. Chesné, V. Garnier, R. Scandolo and N. Vermeire for technical assistance, A. Bourroche for text translation and M.-E. Marmillod who typed the manuscript. 


\section{References}

Betteridge, K.J., Eaglesome, M.D., Randall, G.C.B. \& Mitchell, D. (1980) Collection, description and transfer of embryos from cattle 10-16 days after oestrus. J. Reprod. Fert. 59, 205-216.

Dalla Porta, M.A. (1982) Action antilutéolytique de l'embryon chez les bovins : conséquences sur la mortalité embryonnaire, p. 54. Thèse de Doctorat $3 \mathrm{e}$ cycle, Université Paris 6.

Elsden, R.P., Nelson, L.D. \& Seidel, J.R. (1978) Superovulating cows with FSH and PMSG. Theriogenology 9, 17-26.

Godkin, J.D., Bazer, F.W., Moffatt, J., Sessions, F. \& Roberts, R.M. (1982) Purification and properties of a major, low molecular weight protein released by the trophoblast of sheep blastocysts at Day 13-21. J. Reprod. Fert. 65, 141-150.

Heyman, Y., Camous, S., Fèvre, J. \& Martal, J. (1982) Maintien du corps jaune après transplantation utérine de vésicules trophoblastiques chez la vache et la brebis cyclique. In Transfert d'Embryons chez les Mammiferes, p. 92, Abstr.

Humblot, P., Dalla Porta, M.A. \& Schwartz, J.L. (1982) Action antilutéolytique de l'embryon chez les bovins. II. Effets d'extraits embryonnaires et de PGE2 sur la fonction lutéale. In Transfert d'Embryons chez les Mammiferes, p. 34, Abstr.

Ilgren, E.B. (1981) On the control of the trophoblastic giant-cell transformation in the mouse: homotypic cellular interactions and polyploïdy. J. Embryol. exp. Morph. 62, 183-202.

Lawson, R.A.S., Parr, R.A. \& Cahill, L.P. (1983) Evidence for maternal control of blastocyst growth after asynchronous transfer of embryos to the uterus of the ewe. J. Reprod. Fert. 67, 477-483.

Markette, K.L., Seidel, G.E., Jr \& Elsden, R.P. (1980) Embryonic loss after bovine embryo transfer. Theriogenology 13, p. 105, Abstr.

Martal, J. (1981a) Régulation endocrinienne du corps jaune. In L'utérus de la Vache, pp. 79-100. Eds A. Constantin \& E. Meissonnier. Sté française de Buiatrie, E.N.V.A. Maisons-Alfort.

Martal, J. (1981b) Control of luteal function during early pregnancy in sheep. J. Reprod. Fert., Suppl. 30, 201210.

Martal, J., Lacroix, M.C., Loudes, C., Saunier, M. \& Wintenberger-Torrès, S. (1979) Trophoblastin, an antiluteolytic protein present in early pregnancy in sheep. J. Reprod. Fert. 56, 63-73.

Ménézo, Y. (1976) Milieu synthétique pour la survie et la maturation des gamètes et pour la culture de l'oeuf fécondé. C. r. hebd. Séanc. Acad. Sci. Paris D 282, 1967-1970.

Moor, R.M. \& Rowson, L.E.A. (1966a) Local uterine mechanisms affecting luteal function in the sheep. $J$. Reprod. Fert. 11, 307-310.

Moor, R.M. \& Rowson, L.E.A. (1966b) The corpus luteum of the sheep: functional relationship between the embryo and the corpus luteum. J. Endocr. 34, 233-239.

Moor, R.M. \& Rowson, L.E.A. (1966c) Local maintenance of the corpus luteum in sheep with embryos transferred to various isolated portions of the uterus. J. Reprod. Fert. 12, 539-550.

Northey, D.L. \& French, L.R. (1980) Effect of embryo removal and intrauterine infusion of embryonic homogenates on the life span of the bovine corpus luteum. J. Anim. Sci. 50, 298-302.

Renard, J.P., Heyman, Y. \& du Mesnil du Buisson, F. (1977) Unilateral and bilateral cervical transfer of bovine embryos at the blastocyst stage. Theriogenology 7, 189-192.

Renard, J.P., Heyman, Y. \& Ozil, J.P. (1980) Importance of gestation losses after non-surgical transfer of cultured and non-cultured bovine blastocysts. Vet. Rec. 107, 152-153.

Robinson, T.J. (1965) Use of progestagen-impregnated sponges inserted intravaginally or subcutaneously for the control of the oestrous cycle in the sheep. Nature, Lond. 206, 39-41.

Rowson, L.E.A. \& Moor, R.M. (1967) The influence of embryonic tissue homogenate infused into the uterus on life-span of the corpus luteum in the sheep. $J$. Reprod. Fert. 13, 511-516.

Shelton, J.N. (1965) Identification of progesterone of high activity for the control of the oestrous cycle in the sheep. Nature, Lond. 206, 156-158.

Tervit, H.R., Whittingham, D.G. \& Rowson, L.E.A. (1972) Successful culture in vitro of sheep and cattle ova. J. Reprod. Fert. 30, 493-497.

Wintenberger-Torrès, S. (1967) Etude expérimentale de la migration tubaire des oeufs et de leur segmentation chez la Brebis. D.Sc. thesis, Faculty of Science, Paris.

Received 8 July 1983 